\title{
Recent Advances in Understandings Towards Pathogenesis and Treatment for Intrauterine Adhesion and Disruptive Insights from Single-Cell Analysis
}

\author{
Ross Ka-Kit Leung ${ }^{1,2}$ (D) Yixin Lin ${ }^{1,2} \cdot$ Yanhui Liu ${ }^{1,2}$ \\ Received: 6 August 2020 / Accepted: 1 October 2020 / Published online: 30 October 2020 \\ (C) The Author(s) 2020
}

\begin{abstract}
Intrauterine adhesion is a major cause of menstrual irregularities, infertility, and recurrent pregnancy losses and the progress towards its amelioration and therapy is slow and unsatisfactory. We aim to summarize and evaluate the current treatment progress and research methods for intrauterine adhesion. We conducted literature review in January 2020 by searching articles at PubMed on prevention and treatment, pathogenesis, the repair of other tissues/organs, cell plasticity, and the stem cell-related therapies for intrauterine adhesion. A total of 110 articles were selected for review. Uterine cell heterogeneity, expression profile, and cell-cell interaction were investigated based on scRNA-seq of uterus provided by Human Cell Landscape (HCL) project. Previous knowledge on intrauterine adhesion (IUA) pathogenesis was mostly derived from correlation studies by differentially expressed genes between endometrial tissue of intrauterine adhesion patients/animal models and normal endometrial tissue. Although the TGF- $\beta 1 /$ SMAD pathway was suggested as the key driver for IUA pathogenesis, uterine cell heterogeneity and distinct expression profile among different cell types highlighted the importance of single-cell investigations. Cell-cell interaction in the uterus revealed the central hub of endothelial cells interacting with other cells, with endothelial cells in endothelial to mesenchymal transition and fibroblasts as the strongest interaction partners. The potential of stem cell-related therapies appeared promising, yet suffers from largely animal studies and nonstandard study design. The need to dissect the roles of endometrial cells, endothelial cells, and fibroblasts and their interaction is evident in order to elucidate the molecular and cellular mechanisms in both intrauterine adhesion pathogenesis and treatment.
\end{abstract}

Keywords Intrauterine adhesion (IUA) $\cdot$ Cell heterogeneity $\cdot$ Cell-cell interaction $\cdot$ TGF- $\beta 1 /$ SMAD pathway $\cdot$ Molecular mechanism

\section{Statement of Significance}

\begin{tabular}{lcc}
\hline Problem or issue & What is already known & What this paper adds \\
IUA causes severe & TGF- $\beta$ 1/SMAD & Analyses of uterine \\
gynecological & pathway is most & cell heterogeneity \\
disorders, but the & likely to play a & and cellular \\
prevention & central role in IUA & expression profile \\
strategies and & pathogenesis while & indicate that the \\
treatments have & other candidates & previous research \\
& &
\end{tabular}

Ross Ka-Kit Leung and Yixin Lin contributed equally to this work.

Ross Ka-Kit Leung

rossleung2020@163.com

1 Dongguan Maternal and Child Health Care Hospital, Dongguan 523120, China

2 Dongguan Institute of Reproductive and Genetic Research, Dongguan 523120, China been unsatisfactory and improvements are limited. Current knowledge on IUA pathogenesis was mostly derived from tissue studies without considering the multicellular structures and their orchestration in the endometrial tissue and in-depth mechanistic investigations. Development of stem cell-related therapies is limited. were listed. Molecules and signaling pathways associated with cell plasticity were also listed. Stem cell-related therapies were proved to be effective in animal and clinical studies. 


\section{Introduction}

Intrauterine adhesion (IUA) is a gynecological disease characterized by partial or full adhesion of the anterior and posterior walls of the uterine cavity after endometrial injury. The clinical manifestations include menstrual irregularities, amenorrhea, infertility, placenta previa, recurrent miscarriage, premature delivery, placental adhesions, difficulties in embryo implantation, and abnormal placental development, but there are also asymptomatic intrauterine adhesions [1]. The main causes include miscarriage curettage [2], postpartum curettage [2], myomectomy [3], and endometrial ablation [4]. The German doctor Fritsch reported the first case of IUA in 1894, and the Israeli obstetrician and gynecologist Asherman made a complete description of the disease for the first time in 1948 [5]. Therefore, IUA is also known as Asherman's syndrome (AS).

The treatment for IUA is mainly hysteroscopic surgery followed by re-adhesion prevention. However, Chen et al. [6] found that the re-adhesion rate after treatment of mild and moderate IUA was $30 \%$ and as high as $62.5 \%$ for severe cases. Moreover, the pregnancy rate was only $22.5 \sim 33.3 \%$ [6], which is far from satisfactory.

Besides IUA, there are two related pathologies worth paying attention to: endometriosis and absolute uterine factor infertility (AUFI). Endometriosis is on one extreme a condition that endometrial cells grow outside the uterine cavity as functional glands and stroma. They undergo cyclic proliferation and breakdown, similar to what happens in the normal endometrium. The difference is that the internal bleeding usually cannot be cleared, which leads to an outcome as identified in IUA, and inflammations result in scar formation and adhesions during repair. A comprehensive review about the molecular and cellular pathogenesis of endometriosis can be found in [7]. The other extreme is a condition without the uterus at all or a nonfunctional one. Attempts were made to resume the functionalities by uterus transplantation and several livebirths have already been reported [8-10]. In particular, uterine tissue transplants were employed to assess both endometriosis and uterine repair of a partially defect uterus $[11,12]$. Key insights from these studies into IUA research include the following: (1) endometrial functionalities can be reconstructed, which is reflected by the pathological conditions of endometriosis, and uterine tissue transplant where pregnancy was observed in the once nonfunctional uterus; and (2) the usefulness of cellular models that elucidate the fates of cell differentiation and functional response towards pathological and pregnant conditions. We conducted literature review in January 2020 by searching articles at PubMed on prevention and treatment, pathogenesis, the repair of other tissues/organs, cell plasticity, and the stem cell-related therapies for IUA. A total of 110 articles were selected for review.
Prevention and Treatment Options for IUA and Their Effectiveness

Meta-analysis studies did not suggest the usefulness of interventions for IUA. Bosteels et al. [13] reported that no bio-gel methods could conclusively increase pregnancy rate after undergoing hysteroscopic surgery. Healy et al. [14] showed that no strong evidence to prove that hyaluronic acid gel, polyethene oxide-carboxymethyl cellulose sodium gel, or estrogen could prevent IUA. Johary et al. [15] suggested that estrogen be combined with other ancillary treatment methods, for example, intrauterine devices (IUDs), Foley catheter, hyaluronic acid gel, or amnion graft, to reach better pregnancy rates and live birth rates. Likewise, IUD needs to be combined with other ancillary treatments such as hormone therapy, Foley catheter, hyaluronic acid gel, or amnion graft to obtain maximal outcomes [16]. Khan and Goldberg [17] suggested that stem cell therapy is a significantly better choice than current strategies. Kou et al. [18] suggested that using IUDs/gels to deliver therapeutic factors (such as hormones and/or stem cells) to the injured uterine site may be an effective prevention method, which lacked further verification.

Studies analyzed by Johary et al. [15] found that combining estrogen and other adjunctive therapies have found that the pregnancy rate after treatment is between 8 [19] and 90\% [20], and the live birth rate is between 5.2 [17] to 70\% [20]. This treatment outcome was better than using estrogen alone [21-23]. Similarly, IUD combined with other adjunctive treatments had a better outcome than using IUD only, but the conception rate and live birth rate were also unstable [16]. Therefore, there is a pressing need for the development of effective and stable prevention and treatment methods for IUA. Due to the limited understanding of IUA pathogenesis and the normal repair mechanism of damaged endometrium, it is hard to develop targeted methods to efficiently promote the regeneration of endometrium. The study on IUA pathogenesis should be the basis of the development of new prevention and treatment methods for IUA.

\section{IUA Pathogenesis}

\section{Research Progress and Its Limitations}

IUA is a phenomenon that fibrosis occurs in the damaged endometrium without adequate self-repair [22, 24, 25]. Several studies reported highly expressed fibrotic markers such as TGF- $\beta$ in the endometrial tissue of IUA patients or animal models [26-31]. The TGF- $\beta 1 /$ SMAD pathway was shown to play a leading role in the molecular network that induces fibrosis in various organs [32]. Current research on IUA pathogenesis has mainly been based on this pathway. Reviewing their methodologies (Fig. 1), previous studies 
Fig. 1 Mainstream methodology for the current research in IUA pathogenesis

Endometrium tissue of IUA
patients/animal models

Normal endometrium tissue of human/laboratory animals

\section{Compared the expression level of some molecules or their expression profiles}<smiles>C1CC2CCCC(C1)C2</smiles>

Found out the differentially expressed molecules (TGF- $\beta$, Smad3, Smad7, Collagen, miR-29b, etc.)

\section{Conclusion/inference: these molecules are involved in IUA pathogenesis}

mainly identified differentially expressed proteins/miRNAs/ mRNAs between the endometrial tissue of the IUA patients and normal individuals, or IUA and normal experimental animal models, and inferred that these molecules are involved in IUA pathogenesis (Fig. 2).

Salma et al. [31] showed that the levels of TGF- $\beta 1$ and SMAD3 in IUA patients or experimental animal models had been higher than those in the control group, while SMAD7 was significantly reduced. Therefore, they speculated that TGF- $\beta 1 /$ SMAD3/SMAD7 signaling pathway is the main regulator of IUA pathogenesis. Xue et al. [27] compared the endometrial tissue of IUA patients with that of normal individuals and found that the expression of TGF- $\beta$ and CCN 2 in the former was higher and suggested that TGF- $\beta$ and $\mathrm{CCN} 2$ were related to IUA pathogenesis. They also found that the activity of the NF- $\mathrm{KB}$ pathway is positively correlated with TGF- $\beta$ and $\mathrm{CCN} 2$ expression. When the NF- $\mathrm{KB}$ signaling pathway was inhibited with SN50, lower expression of TGF- $\beta$ resulted. Hence, the conjectured activation of the $\mathrm{NF}-\kappa \mathrm{B}$ pathway is also related to the formation of IUA. Wang et al. [33] also reported that NF- $\mathrm{KB}$ was highly expressed in endometrial tissues of IUA patients and therefore
Fig. 2 Potential molecular mediators involved in IUA pathogenesis

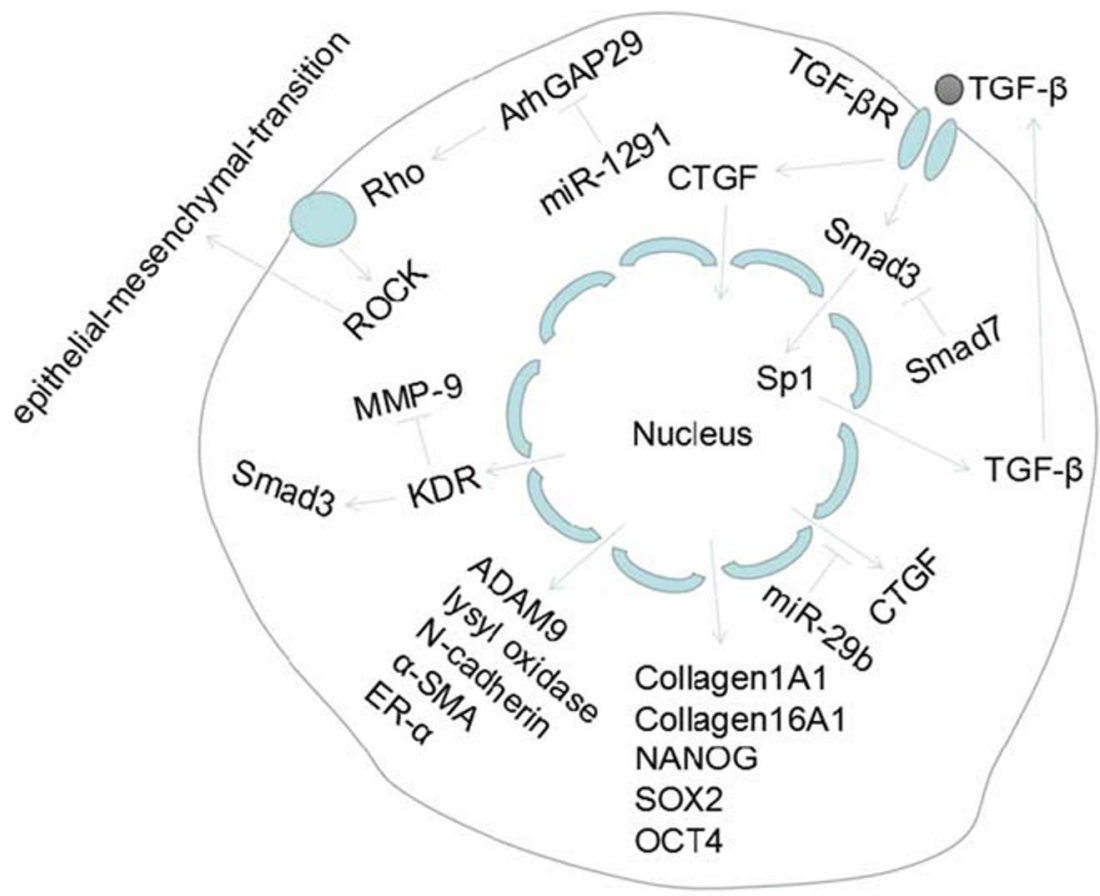

Cell in endometrium tissue 
a putative pathogenic factor for IUA. Chen et al. [30] found that the expression of KDR in IUA tissues was significantly higher than that of the normal counterpart, and also the expression of KDR was positively correlated with the severity of IUA. Silencing KDR could upregulate MMP-9 and affect TGF- $\beta 1 /$ SMAD pathway to inhibit the occurrence and

Table 1 Summary of previous work on IUA pathogenesis

\begin{tabular}{|c|c|c|c|c|c|c|}
\hline \multirow[t]{2}{*}{ Species } & \multirow[t]{2}{*}{ Tissue } & \multicolumn{2}{|l|}{ Sample size } & \multirow{2}{*}{$\begin{array}{l}\text { Cell line/cell } \\
\text { model }\end{array}$} & \multirow{2}{*}{$\begin{array}{l}\text { Molecules/pathways } \\
\text { associated with IUA } \\
\text { pathogenesis }\end{array}$} & \multirow[t]{2}{*}{ References } \\
\hline & & Human & Animal model & & & \\
\hline $\begin{array}{l}\text { Human; } \\
\text { rabbit }\end{array}$ & $\begin{array}{l}\text { Blood/uterine } \\
\text { tissue }\end{array}$ & $\begin{array}{l}60 \text { patients and } 30 \text { fertile } \\
\text { women }\end{array}$ & $\begin{array}{l}18 \text { IUA rabbit models and } 18 \\
\text { mature female fertile rabbits }\end{array}$ & - & Smad3; Smad7; TGF- $\beta 1$ & {$[31]$} \\
\hline $\begin{array}{l}\text { Human; } \\
\text { rat }\end{array}$ & $\begin{array}{l}\text { Endometrial } \\
\text { tissue }\end{array}$ & $\begin{array}{l}40 \text { intrauterine adhesion } \\
\text { tissues and } 20 \text { normal } \\
\text { endometrium tissues }\end{array}$ & $\begin{array}{l}30 \text { IUA rats (phenol mucilage } \\
\text { treatment), } 15 \text { rats for sham } \\
\text { group (with mock treatment), and } \\
15 \text { rats for normal group (with no } \\
\text { treatment) }\end{array}$ & - & $\mathrm{NF}-\mathrm{kB}$ & {$[33]$} \\
\hline $\begin{array}{l}\text { Human; } \\
\text { rat }\end{array}$ & $\begin{array}{l}\text { Endometrial } \\
\text { tissue }\end{array}$ & $\begin{array}{l}92 \text { patients and } 86 \text { women in } \\
\text { control group }\end{array}$ & $\begin{array}{l}50 \text { rats were divided into control } \\
\text { group, sham group, model group, } \\
\text { NC-siRNA group, and } \\
\text { KDR-siRNA group, with } 10 \text { rats } \\
\text { in each group }\end{array}$ & - & $\begin{array}{l}\text { KDR; TGF- } \beta 1 / \text { SMAD } \\
\text { pathway; MMP-9 }\end{array}$ & {$[30]$} \\
\hline $\begin{array}{l}\text { Human; } \\
\text { mou- } \\
\text { se }\end{array}$ & $\begin{array}{l}\text { Women } \\
\text { endometrial } \\
\text { tissue; } \\
\text { mouse } \\
\text { uterine } \\
\text { horns }\end{array}$ & $\begin{array}{l}19 \text { women with IUA and } 16 \\
\text { disease-free women as } \\
\text { control group }\end{array}$ & Not indicated & - & SOX2; NANOG; OCT4 & {$[34]$} \\
\hline Rat & $\begin{array}{l}\text { Endometrial } \\
\text { tissue }\end{array}$ & - & $\begin{array}{l}6 \text { rats in IUA group and } 6 \text { in sham } \\
\text { group }\end{array}$ & - & $\begin{array}{l}\text { TGF- } \beta 1 / \text { BMP7/SMAD } \\
\text { pathway; } \\
\text { epithelial-mesenchymal } \\
\text { transition (EMT) }\end{array}$ & [29] \\
\hline $\begin{array}{l}\text { Human; } \\
\text { rat }\end{array}$ & $\begin{array}{l}\text { Endometrial } \\
\text { tissue }\end{array}$ & $\begin{array}{l}76 \text { IUA patients and } 20 \\
\text { samples of normal } \\
\text { endometrium }\end{array}$ & $\begin{array}{l}70 \text { rats in experimental group and } \\
10 \text { in control group }\end{array}$ & - & $\begin{array}{l}\text { TGF- } \beta 1 ; \text { MMP-9; ER } \alpha \\
\text { SDF-1/CXCR-4 axis }\end{array}$ & {$[26]$} \\
\hline Rat & $\begin{array}{l}\text { Endometrial } \\
\text { tissue }\end{array}$ & $\begin{array}{l}12 \text { rat IUA models, } 4 \text { rats in } \\
\text { sham-operated group, and } \\
4 \text { in control group }\end{array}$ & - & - & $\begin{array}{l}\text { miR-29b; } \\
\text { Sp1/TGF- } \beta 1 / \text { SMAD-C- } \\
\text { TGF }\end{array}$ & {$[35]$} \\
\hline Human & $\begin{array}{l}\text { Endometrial } \\
\text { tissue }\end{array}$ & $\begin{array}{l}3 \text { patients with severe IUA } \\
\text { (the sample size of normal } \\
\text { endometrium was not } \\
\text { indicated) }\end{array}$ & - & - & $\begin{array}{l}\text { miR-513a-5p; } \\
\text { miR-135a-3p; miR-543; } \\
\text { N-cadherin; collagen } \\
\text { 16A1; ADAM9; lysyl } \\
\text { oxidase }\end{array}$ & {$[36]$} \\
\hline $\begin{array}{l}\text { Human; } \\
\text { mou- } \\
\text { se }\end{array}$ & $\begin{array}{l}\text { Endometrial } \\
\text { tissue }\end{array}$ & $\begin{array}{l}39 \text { patients with IUAs and } \\
28 \text { normal control cases }\end{array}$ & $\begin{array}{l}12 \text { mice were divided into three } \\
\text { groups: IUAs }(n=3), \text { miR-1291 } \\
\text { antagomir }(n=3), \text { and } \mathrm{NC}(n=3)\end{array}$ & - & $\begin{array}{l}\text { miR-1291; ArhGAP29; } \\
\text { RhoA/ROCK1 EMT } \\
\text { pathway }\end{array}$ & [37] \\
\hline Human & $\begin{array}{l}\text { Endometrial } \\
\text { tissue }\end{array}$ & Not indicated & - & $\begin{array}{l}\text { Primary } \\
\text { endome- } \\
\text { trial } \\
\text { stromal } \\
\text { cells } \\
\text { (ESCs) }\end{array}$ & $\begin{array}{l}\text { miR-29b; TGF- } \beta 1 / \mathrm{SMAD} \\
\text { pathway }\end{array}$ & {$[38]$} \\
\hline Human & $\begin{array}{l}\text { Endometrial } \\
\text { tissue }\end{array}$ & $\begin{array}{l}70 \text { endometrium tissue from } \\
\text { IUA patients, } 15 \text { from } \\
\text { patients with uterine } \\
\text { septum, and } 15 \text { normal } \\
\text { endometrium }\end{array}$ & - & RL95-2 & $\begin{array}{l}\text { TGF- } \beta ; \mathrm{CCN} 2 ; \mathrm{NF}-\mathrm{kB} \\
\text { pathway }\end{array}$ & {$[27]$} \\
\hline Human & $\begin{array}{l}\text { Endometrial } \\
\text { tissue }\end{array}$ & $\begin{array}{l}30 \text { endometrial tissues from } \\
\text { IUA patients and } 15 \\
\text { normal endometrial } \\
\text { tissues }\end{array}$ & - & $\begin{array}{l}\text { Primary } \\
\text { endome- } \\
\text { trial } \\
\text { stromal } \\
\text { cells } \\
\text { (ESCs) }\end{array}$ & $\begin{array}{l}\text { miRNA-326; } \\
\text { TGF- } \beta 1 / \operatorname{Smad} 3\end{array}$ & {$[25]$} \\
\hline
\end{tabular}


development of IUA, so KDR was thought to play an important role in the formation of IUA. Xiao et al. [34] found that in LPS-induced IUA rat models, against the control group, the expression of SOX2, NANOG, and OCT4 increased significantly. They also found that in IUA patients, the expression of NANOG was significantly higher than that of normal people. Collectively, SOX2, NANOG, and OCT4 might be involved in the pathogenesis of IUA. Guo et al. [29] found that the TGF- $\beta 1 /$ BMP 7/SMAD pathway and epithelialmesenchymal transition (EMT) could promote the development of IUA. EMT has also been found associated with development of other pathological conditions including Zhou et al. [26] who found that the expressions of TGF- $\beta 1$, MMP-9, and ER $\alpha$ in endometrial tissues of IUA patients or rat models were significantly higher than those of the control group. Moreover, the expression of these molecules was significantly higher in patients with severe than mild or moderate IUA. They proposed that abnormal activation of fibrosis and overexpression of $\mathrm{ER} \alpha$ may be involved in the formation of mild and moderate IUA, and the SDF1/CXCR-4 axis may also be involved in the immune response during IUA formation. Since there were few studies on the immune response in IUA pathogenesis, the role of the SDF-1/CXCR-4 axis in IUAs as an inflammatory mediator requires further verification.

The regulatory effects of miRNAs on the formation or development of IUA were studied. $\mathrm{Li}$ et al. [35] found that the expression of COL1A1, $\alpha$-SMA, CTGF, and the transcription factor SP1 increased in the endometrial tissue of the rat IUA model, while the expression of E-cadherin and microRNA-29 (miR-29) decreased. The study further found that miR-29 inhibited tissue fibrosis by downregulating the Sp1-TGF- $\beta 1$ / SMAD-CTGF pathway. Liu et al. [36] applied microarray analysis to profile the mRNA and miRNA expression of endometrial tissues. There were 26 miRNAs and 1180 mRNAs significantly differentially expressed between the patients with severe IUA and normal individuals. Real-time PCR experiments confirmed that miR-513a-5p and miR-135a-3p were upregulated, while miR-543 was downregulated. Their target genes $\mathrm{CDH} 2$ (N-cadherin) and COL16A1 (collagen 16A1) were upregulated, while ADAM9 and lysyl oxidase were downregulated. How these molecules participate in the formation or development of IUA were unanswered though. $\mathrm{Xu}$ et al. [37] found that miR-1291, as an upstream molecule of ArhGAP29, promotes fibrosis of the endometrium by negatively regulating the RhoA/ROCK1 EMT pathway.

In addition to the abovementioned studies on endometrial tissues of IUA patient or animal models, there were also studies using human endometrial stromal cells as cell models to study the IUA pathogenesis. Li et al. [38] validated their findings of miRNA-29b inhibition of the development of IUA by regulating the TGF- $\beta 1 /$ SMAD pathway in human endometrial stromal cells. Ning et al. [25] used microarray to evaluate the miRNA expression profiles of endometrial tissue and normal endometrial tissue in patients with IUA and validated that miRNA-326 could inhibit endometrial fibrosis by inhibiting the TGF- $\beta 1 /$ smad 3 pathway. Therefore, miRNA- $29 b$ and miRNA-326 were potential candidates for IUA treatment and further studies. The recent studies on IUA pathogenesis are summarized in the Table 1.

Zhu et al. [39] suggested that the Hippo pathway may form a complex molecular network with the TGF- $\beta$ and Wnt pathways to control the development of endometrial fibrosis and their belief was based on (1) the important role of TGF- $\beta$ pathway in IUA pathogenesis, (2) the role of Hippo pathway in the development of normal endometrium [40, 41], (3) the important role of Hippo in fibrosis of other tissues [42, 43], and (4) the crosstalk of Hippo pathway with the TGF- $\beta$ and Wnt pathways in other tissue or cell models [42, 44-48]. However, no direct evidence indicating the role of Hippo pathway in IUA pathogenesis was presented. Therefore,

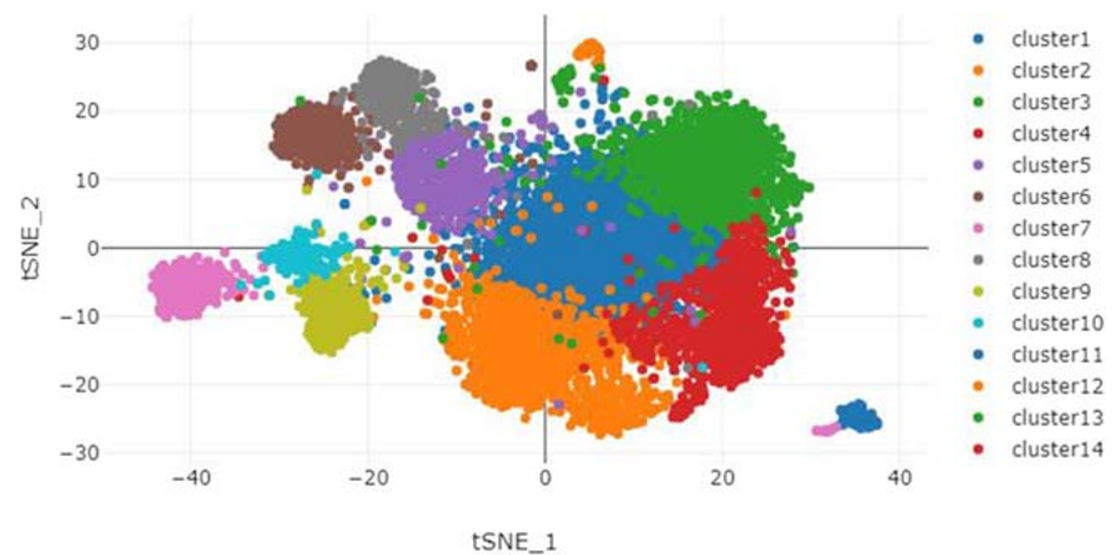

Fig. 3 Various cell types in uterus. cluster1: endothelial cell_COL15A1 high; cluster2: endothelial cell_ESM1 high; cluster3: endothe-iial cell_IL6 high; cluster4: endothelial cell_SOCS3 high; cluster5: smooth muscle cell_MYL9 high; cluster6: stromal cell_RGS5 high; cluster7: fibroblast; cluster8: smooth muscle cell_PDK4 high; cluster9: smooth muscle cell_
ACTG2 high; cluster10: stromal cell_ERRFI1 high; cluster11: endometrial cell; cluster12: M1 Macrophage; cluster13: T cell; cluster14: endothelial cell in EMT; cluster15: endothelial cell_FABP4 high; cluster16: Mast cell; cluster17: luminal epithelium 
Gene searching results of KDR

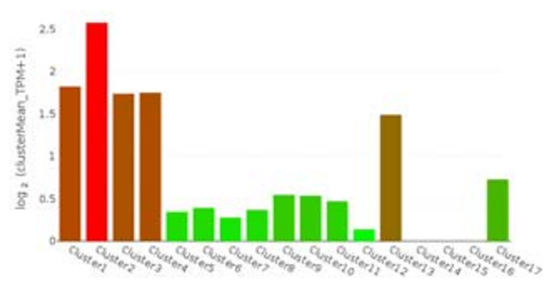

Gene searching results of $\mathrm{CXCR4}$

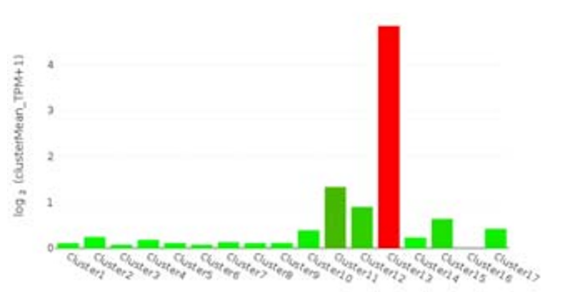

Gene searching results of SMAD3

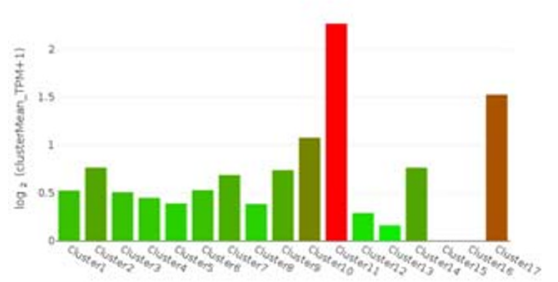

Gene searching results of NFKB1

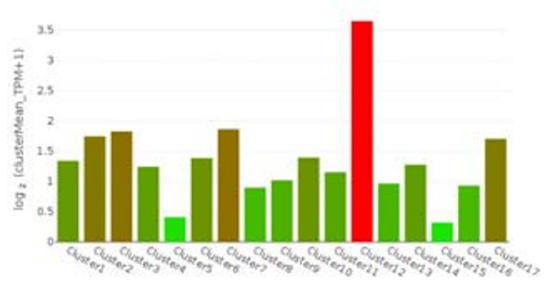

Fig. 4 Uterine cellular expression profile related to IUA pathogenesis. cluster1: endothelial cell_COL15A1 high; cluster2: endothelial cell ESM1 high; cluster3: endothelial cell_IL6 high; cluster4: endothelial cell_SOCS3 high; cluster5: smooth muscle cell_MYL9 high; cluster6: stromal cell_RGS5 high; cluster7: fibroblast; cluster8: smooth muscle
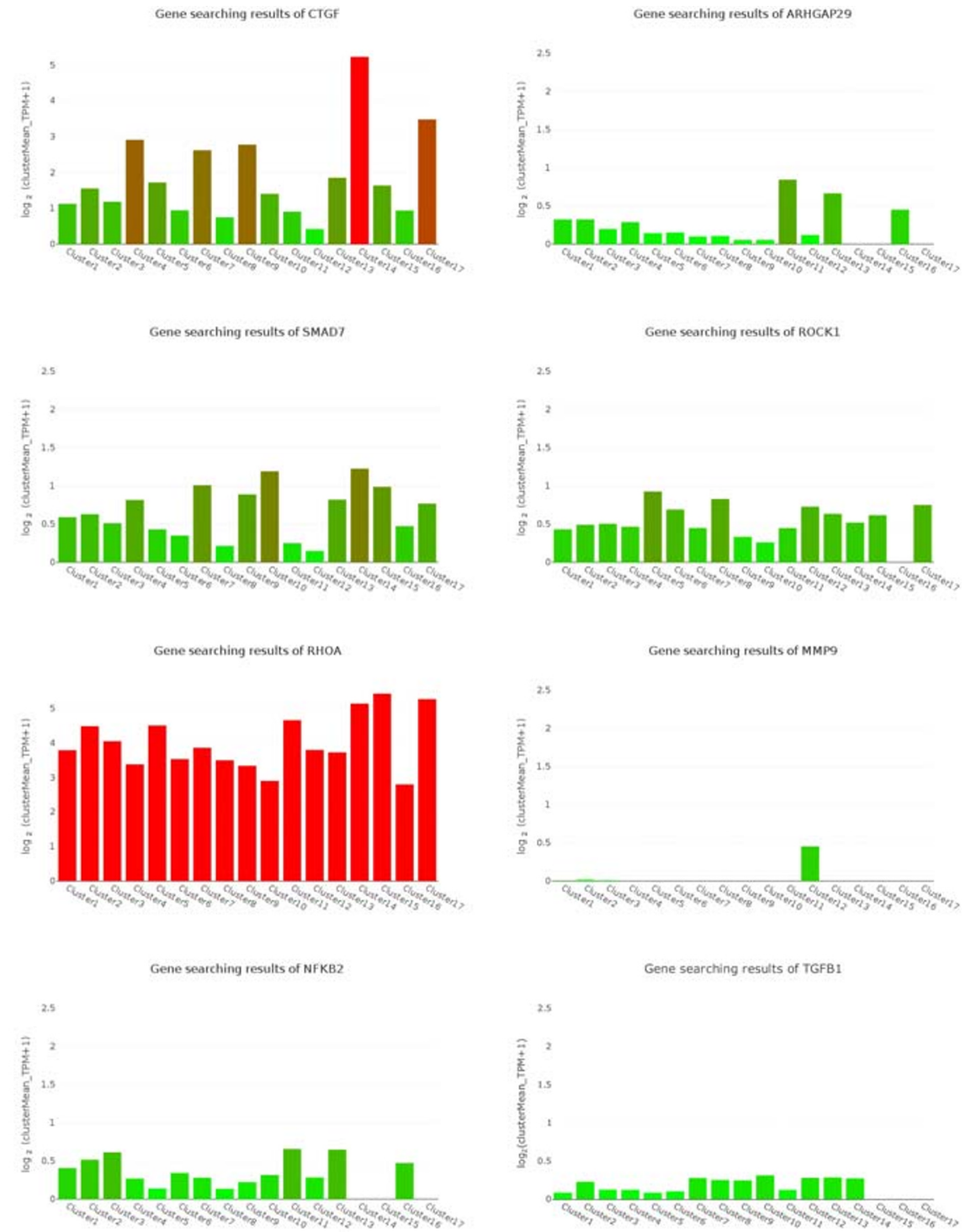

cell PDK4 high; cluster9: smooth muscle cell ACTG2 high; cluster10: stromal cell_ERRFI1 high; cluster11: endometrial cell; cluster12: M1 macrophage; cluster13: T cell; cluster14: endothelial cell in EMT; cluster15: endothelial cell_FABP4 high; cluster16: mast cell; cluster17: luminal epithelium whether the Hippo pathway is the response or driver needs further verification.

In spite of a large number of gene expression and pathway analysis studies on IUA, the multicellular structures in the endometrium could undermine the validity of the aforementioned research findings. For example, single-cell RNA sequencing has unveiled immune system heterogeneity by identifying novel distinct immune cell subsets [49], which cannot be accomplished by tissue studies. Tumor heterogeneity such as the full spectrum of mutations can only be accurately studied by single-cell methods [50]. Note that the uterus consists of the uterine body and the cervix and intrauterine adhesion refers to the adherence of the endometrial surfaces with fibrotic scar. The endometrium is cell-rich, consisting of secretory, cilia, and stromal cells. Studies that take samples from the uterus do not only retrieve these cells, but also epithelial, myometrium, endothelial, and possibly also some other cells. For example, epithelial and stromal cells represent two distinct groups and their molecular markers and response are different [51-53]. Single-cell methods are options to help pinpoint the underlying causes of IUA pathogenesis.

\section{Uterine Cell Heterogeneity}

Ignoring the complex tissue structure of the uterus and the distinct roles that different cell types may play in the 
pathogenesis of IUA can invalidate the comparison between the normal uterine and IUA tissues to study the pathology and mechanisms. Single-cell sequencing is a powerful technique to overcome the limitations. Han et al. [54] performed singlecell sequencing on each organ/tissue sample of the Chinese Han population, which provided valuable data for revealing the complex cell types in each organ/tissue.

We performed t-SNE analysis based on single-cell sequencing data of the uterus to distinguish multiple types (clusters) of cells in the uterus (Fig. 3), including six types of endothelial cells with different molecular markers, endometrial cells, fibroblasts, luminal epithelium, M1 macrophages, mast cells, three types of smooth muscle cells with different molecular markers, two types of stromal cells with different molecular markers, and $\mathrm{T}$ cells. For examples, in the six types of endothelial cells, endothelial cell_COL15A1 high denotes the endothelial cells expressing COL15A1 significantly compared with the other five, so that COL15A1 can be regarded as a marker of this type of endothelial cells. Similar concepts apply to smooth muscle and stromal cells. Cell heterogeneity is evident in the uterus at molecular level and this lays a solid foundation for studying the role of different cell types during the formation of IUA. In
Fig. 4, the expression profiles of these genes varied a lot in different types of cells, which suggests the distinct roles of these cells during IUA formation. Taking the whole uterus as a whole for research could miss important information; for example, SMAD3 was high in endometrial cell while it was low in endothelial cell FABP4 high, hinting us SMAD3 might not be associated with angiogenesis. Moreover, NFKB1 was high in M1 macrophage while it was low in endothelial cell_FABP4 high, resulting in "no changes" as a whole.

\section{Insufficient Cell Plasticity Model for IUA Pathogenesis}

IUA is the consequence of endometrial fibrosis, so understandings towards the molecular mechanisms of fibrosis in other tissues are informative. We hypothesize that in the injured endometrium, insufficient functional cell renewal capacity will lead to exposure of the wound to pathogens and dead cells, infiltrating immune cells and other effector cells, and ultimately steer the emergent response of a large amount of extracellular matrix secreted to seal the wound, thus forming IUA. Similar phenomena have been observed in cardiac, hepatic, renal, and pulmonary fibrosis [32].

Table 2 Molecules and signaling pathways associated with differentiation and transdifferentiation

\begin{tabular}{|c|c|c|c|c|}
\hline Pathway & Activation/inhibition & Starting cell and ending cells & Remarks & References \\
\hline Notch & Inhibition & Mouse fibroblast $\rightarrow$ cardiomyocytes & - & {$[55]$} \\
\hline \multirow[t]{2}{*}{ JAK-STAT } & Activation & Mouse neural stem cells/fibroblasts $\rightarrow$ iPSCs & - & {$[56]$} \\
\hline & Inhibition & Mouse embryonic fibroblasts $\rightarrow$ cardiomyocytes & With expression of OSKM and Bmp4 & {$[57]$} \\
\hline \multirow[t]{2}{*}{ TGF- $\beta$} & \multirow[t]{2}{*}{ Inhibition } & Mouse embryonic fibroblasts $\rightarrow$ iPSCs & - & {$[58]$} \\
\hline & & Mesenchymal-type human fibroblasts $\rightarrow$ iPSCs & - & {$[58]$} \\
\hline BMP & Activation & $\begin{array}{l}\text { Mouse fibroblasts } \rightarrow \text { cardiovascular progenitor } \\
\text { cells (CPC) }\end{array}$ & With activation of Wnt and TGF- $\beta$ pathway & [59-62] \\
\hline \multirow[t]{4}{*}{ Wnt } & Activation & Mouse fibroblasts/neural stem cells $\rightarrow$ iPSCs & - & {$[63,64]$} \\
\hline & Inhibition & Mouse fibroblasts $\rightarrow$ cardiomyocyte & With SB431542 & {$[60]$} \\
\hline & \multirow[t]{2}{*}{$\begin{array}{l}\text { Activated by } \\
\text { CHIR99021 }\end{array}$} & Mouse fibroblasts $\rightarrow$ cardiomyocyte & $\begin{array}{l}\text { With Repsox (inhibiting TGF- } \beta \text { signaling), } \\
\text { forskolin (increasing cAMP), and } \\
\text { phosphodiesterase (PDE) } 4 \text { inhibitors } \\
\text { (rolipram and cilomilast) }\end{array}$ & {$[65]$} \\
\hline & & Human fibroblasts $\rightarrow$ neurons & $\begin{array}{l}\text { With inhibition of TGF- } \beta \text { signaling by } \\
\text { SB431542 and transduction } \\
\text { with Ascl1 and Ngn2 }\end{array}$ & {$[66]$} \\
\hline MAPK/ERK & $\begin{array}{l}\text { Inhibited by } \\
\text { PD0325901 }\end{array}$ & Mouse neural progenitor cells $\rightarrow$ iPSCs & - & {$[67]$} \\
\hline \multirow[t]{2}{*}{ ROCK } & \multirow[t]{2}{*}{ Inhibited by Y-27632 } & Mouse fibroblasts $\rightarrow$ cardiomyocytes & - & {$[68]$} \\
\hline & & $\begin{array}{l}\text { Human dermal fibroblasts } \rightarrow \text { induced } \\
\text { multipotent mesenchymal stem cell-like cells } \\
\text { (iMSCs) }\end{array}$ & $\begin{array}{l}\text { With SP600125 (JNK inhibitor), SB202190 } \\
\text { (p38 inhibitor), Go } 6983 \text { (PKC inhibitor), } \\
\text { PD0325901 (ERK1/2 inhibitor), and } \\
\text { CHIR99021, } \\
\text { with or without growth factors } \\
\text { (TGF- } \beta, \text { bFGF, and LIF) }\end{array}$ & {$[69]$} \\
\hline mTOR & Inhibited by Sox 2 & Mouse embryonic fibroblasts $\rightarrow$ iPSC & - & {$[70]$} \\
\hline
\end{tabular}


To test the above hypothesis, the mechanisms of self-repair after endometrial injury followed by the cause of insufficient selfrepair ability should be studied. The molecular mechanisms leading to fibrosis in the endometrium should be one of the first few tasks to work on. While there is little research on exploring the mechanisms of self-repair after endometrial injury, studies on other epithelial tissues can shed some light [71]. In general, when tissue is traumatized without significant infection or inflammation occurs, the ability of self-healing mainly depends on the dedifferentiation/transdifferentiation ability of differentiated cells [72-80]. The molecules and signaling pathways associated with dedifferentiation and transdifferentiation are shown in Table 2. The insufficient cell plasticity model for IUA pathogenesis is as follows. Injured endometrial cells have limited self-repair capacity and are exposed to potentially hostile environments. When stimuli (such as immune response) induced by factors such as pathogens and dead cells reach a certain level, fibroblasts and/or other effector cells are activated to form fibrous tissue to seal the wound. We hypothesize that fibrous tissues between the wounds get connected when they are formed, and eventually cause adhesions between the walls of the uterine cavity (Fig. 5).

\section{Cell-Cell Interaction in Uterus}

Since IUA is mainly the result of fibrotic lesions of endometrial injury, we assessed the interactions between various types of cells in the uterus. Direct interaction between endometrial cells and most other types of cells was weak (Fig. 6), which implies that when the endometrial cells are injured, it is difficult for other cells to receive relevant signals and dedifferentiate or transdifferentiate into endometrial cells, supporting our proposed insufficient cell plasticity model described in "Insufficient Cell Plasticity Model for IUA Pathogenesis." Likewise, immune cells (T cell, M1 macrophage, and mast cell) in the uterus interacted with other cells weakly. It is not known whether this is beneficial or not because cells like macrophages have been reported for their dual roles in disease progression and protection $[81,82]$.

In contrast, the interaction between endothelial cells with others was high. In particular, fibroblasts, stromal cells, and epithelial cells were major targets. It can be conjectured that injured endometrial cells may communicate with other cells via endothelial system and fibroblasts would be the very first one to respond, due to strong
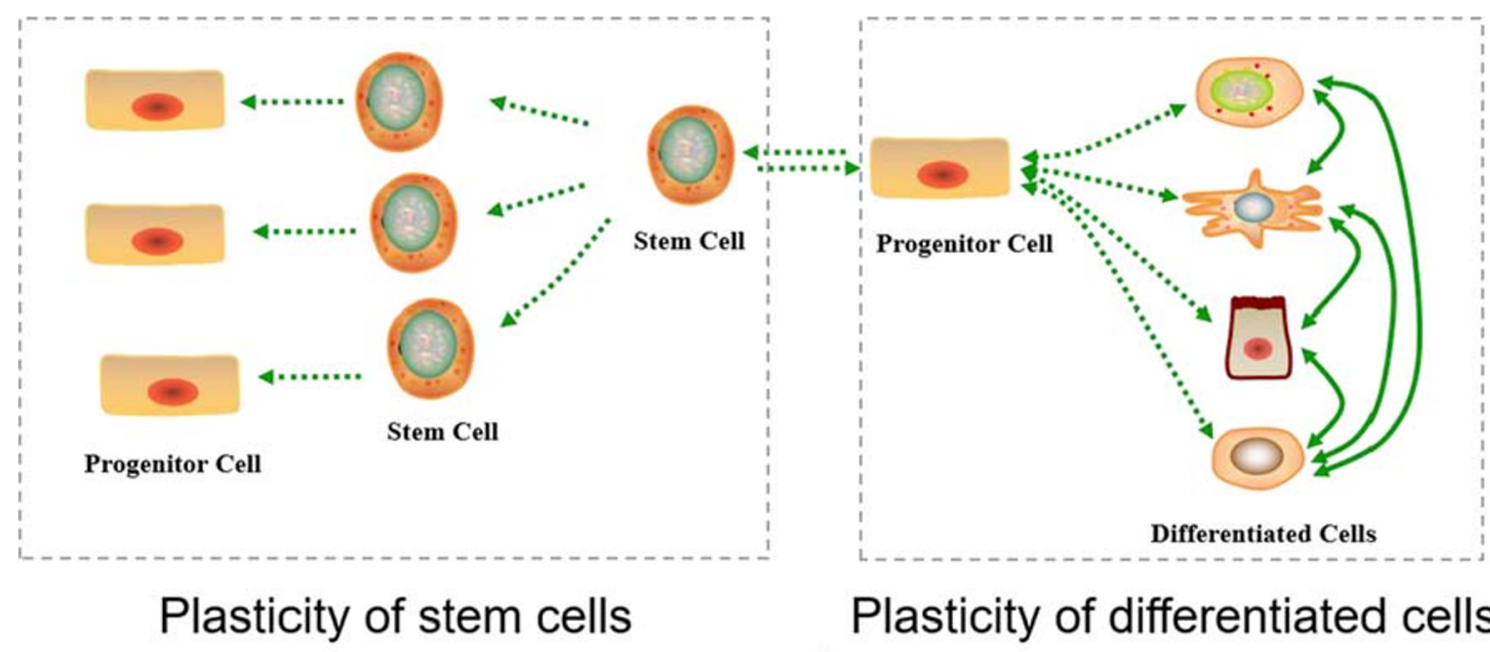

Plasticity of differentiated cells

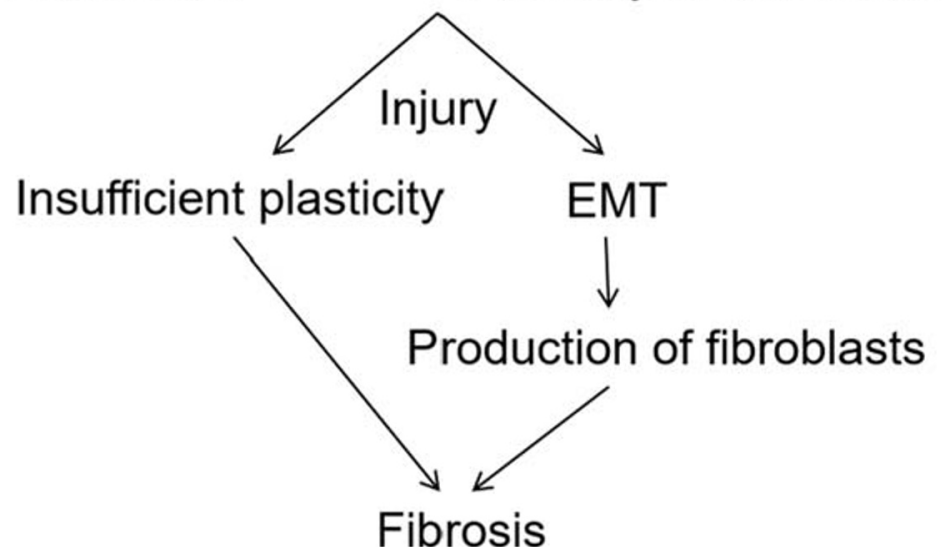

Fig. 5 Schematic diagram of cell plasticity and differentiation 
interaction. It is worth noting that the endothelial cell includes "endothelial cell in EMT" (Fig. 6), which transforms into mesenchymal cells under normal physiological conditions. After the endometrium is injured, EMT can lead to the disintegration of microvascular structures and closely packed epithelioid tissues of the endometrium. Similar pathological development was observed in atherosclerotic lesions [83].

Taking both cell plasticity and cell-cell interaction into consideration, we hypothesized a transdifferentiation route of pericytes and endothelial cells to fibroblasts during the formation of IUA, which is shown in Fig. 8.

\section{Stem Cell-Related Therapies for IUA and Its Molecular Mechanisms}

\section{Research Progress and Limitations}

Many studies have confirmed that transplantation of bone marrow-derived stem cells, hematopoietic stem/progenitor cells, endometrial MSCs, embryonic stem cells, amniotic MSCs, and blood-derived stem cells can effectively promote the endometrial regeneration and menstrual recovery of IUA animal models or patients [84-86]. To improve the endometrial receptivity and improve the therapeutic effect of stem cell transplantation, Zhang et al. [87] combined platelet-rich plasma (PRP) and blood-derived stromal cells in the IUA rat model in order to explore the therapeutic mechanisms. They suggested that menstrual blood-derived stromal cells had a significant effect on the Hippo pathway of endometrial cells and then significantly affected the expression of downstream molecules CTGF, Wnt5a, and Gdf5.

Research on stem cell therapy treating IUA was limited to proving that stem cells are beneficial to the repair of endometrium. Except for the abovementioned study by Zhang et al., there were few studies of stem cell therapy studies for IUA focusing on the molecular mechanism. However, the understanding of molecular mechanism is urgently needed to improve the efficacy of stem cell treatment.

\section{Stem Cell-Derived Extracellular Vesicle Therapy}

\section{Feasibility and Advantages}

Extracellular vesicles are a heterogeneous group of membrane-structured particles derived from cells, including exosomes and microvesicles. They originate from the endosomal system or shedding from the plasma membrane, respectively. They contain proteins, mRNA, and microRNA and involve in intercellular substance exchange and signal transmission. Stem cells were found to affect the repairing of injured cells mainly through paracrine actions [88-91], in which extracellular vesicles $(\mathrm{EV})$ play a key part. EVs
Fig. 6 Heatmap of uterine cellcell interaction

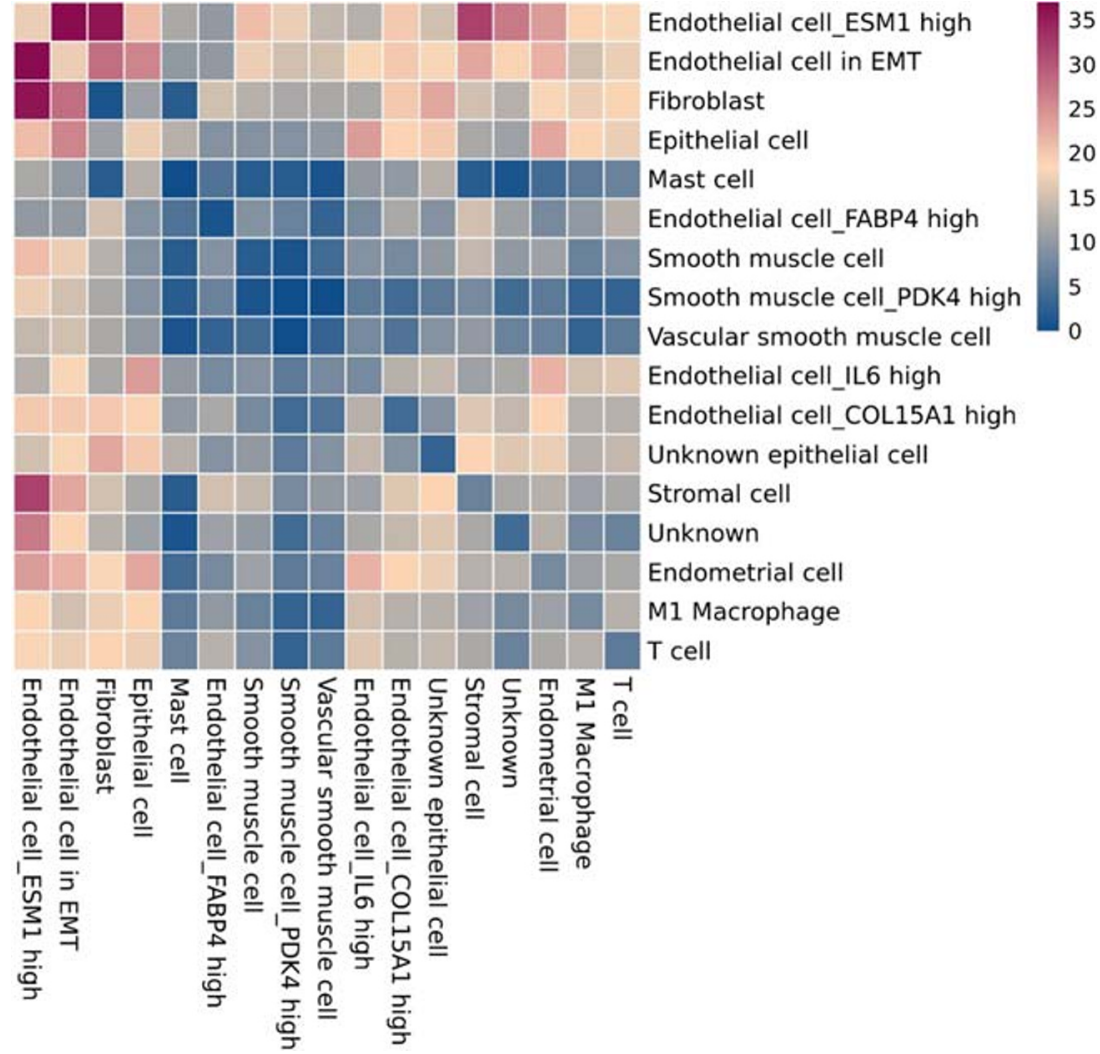


released by MSCs during tissue repair contain paracrine factors such as chemokines, growth factors, and cytokines, which have anti-inflammatory, anti-scarring, and pro-angiogenic effects [92].

Stem cell therapy for IUA is still in the clinical trial stage with very long treatment cycle. If obtaining the patients' stem cells by bone marrow aspiration, the patients have to undergo at least two invasive treatments of bone marrow aspiration plus hysterectomy. Ethical and psychological issues pose a challenge for patients [93]. The uncertainty and experimentation of stem cell therapy raise many ethical concerns. With the extensive development of stem cell-related clinical trials, the International Stem Cell Society has even published related books for patients seeking stem cell therapy to popularize the psychological preparation and purpose of stem cell therapy [94]. How to apply the easy-to-accept IUA treatment method to the clinic is an urgent problem of assisted reproductive medicine. If stem cell-derived EVs can be isolated from culture solution and then injected intravenously, it will greatly facilitate the treatment.

\section{Research Progress and Limitations}

There was only one case study of stem cell-derived EV therapy for IUA, in which enriched EVs from human umbilical cord mesenchymal stem cell culture medium were injected into the right uterine horn of IUA model rats [95]. The results showed that both inflammation and fibrosis in rats were significantly reduced, and angiogenesis was also significantly improved. However, no molecular mechanisms were studied.

\section{Stem Cell-Related Therapies for IUA and Cell Plasticity}

Mesenchymal stem cell-based therapy mainly repairs injured tissues through paracrine signaling (described in "Research Progress and Limitations"). Stem cells also secrete EVs, which are packaged with functional molecules and effect on target cells $[90,95]$. Therefore, the molecular pathways mediated by stem cells or stem cell-derived EVs for damaged tissue repair should be similar. Self-repair of injured tissue depends on the plasticity of differentiated and stem cells (described in "Uterine Cell Heterogeneity"). A possible scenario is that EVs of MSCs improve the plasticity of cells in the injured endometrium, thereby promoting tissue regeneration (Fig. 7). The influence of EVs on the plasticity of target cells is thus a promising primer towards elucidating the molecular mechanisms of stem cell-related therapy. By first questioning the key components in stem cell-derived EVs, followed by identifying the molecules and signaling pathways associated with cell plasticity, mechanistic studies could then be designed to interrogate the key players involved in the repair of the injured endometrium (Fig. 8).
There were studies on searching for paracrine factors functioning in the repair of various injured tissues in animal models, though no related research on the endometrium; they still provide candidates for further studies. For example, in the study of rat models, TGF- $\beta$, FGF-2, angiopoietin-2, IGF-1, VEGF, EGF, bFGF, SDF-1, HGF, and IL-6 were considered to be the main paracrine factors [84, 96-98]. Likewise, in the study of mouse models, NGF, HGF, IL-10, TGF- $\beta 1$, VEGF, IGF-1, angiogenin, and IL-8 were considered to be the main paracrine factors [99-101]. Common factors between these studies include VEGF, TGF- $\beta$, and IGF.

Many studies on the molecular mechanisms of repairing by EVs mainly focused on the skin. Molecules in EVs could affect different molecules/signaling pathways in different types of cells in the skin. MiRNA-21, miRNA-23a, miRNA125b, and miRNA-145 in EVs activated AKT, ERK1/2, Wnt $4 / \beta$-catenin, and STAT3 and inhibited TGF- $\beta /$ SMAD2 in fibroblasts [102-107]. MiRNA-181c and Let-7b in EVs inhibited TLR4 and NF-KB and activated STAT3 and AKT in macrophages [108-110]. EVs activated AKT and Wnt4/ $\beta$ catenin in keratinocytes [104, 105, 111, 112]. MiRNA-126-3p in EVs activated AKT, ERK1/2, and Wnt $4 / \beta$-catenin in endothelial cells [113-115]. Once again, these molecules or pathways can be good starting points for molecular mechanistic studies on EV-treated injured endometrium. Research on the molecular mechanisms of injury-induced plasticity and inflammation-induced plasticity (mentioned in "Insufficient Cell Plasticity Model for IUA Pathogenesis") should provide further insights.

\section{Conclusions and Discussion}

Routine prevention strategies and treatments for IUA were unsatisfactory and reported efficacy from different studies varies. Correlation studies by differentially expressed genes between endometrial tissue of IUA patients/animal models and normal endometrial tissue have not provided conclusive results to innovate effective therapeutics. Stem cell-related therapies, though appeared promising, yet again suffer from largely animal studies and ambiguities from multicellular structures of the endometrium. To overcome the bottleneck, cell plasticity should receive greater attention, and cell-based models or experimental methods will help dissect the problem and understand the molecular mechanisms in both IUA pathogenesis and treatment.

Specifically, comparing the single-cell expression profile of IUA endometrium and normal endometrium should be powerful in providing new molecular information on IUA pathogenesis. Sing-cell methods can also be used to identify molecular markers of subpopulations in endometrium. Those markers are essential tools in lineage tracing to investigate the dedifferentiation and transdifferentiation of different 


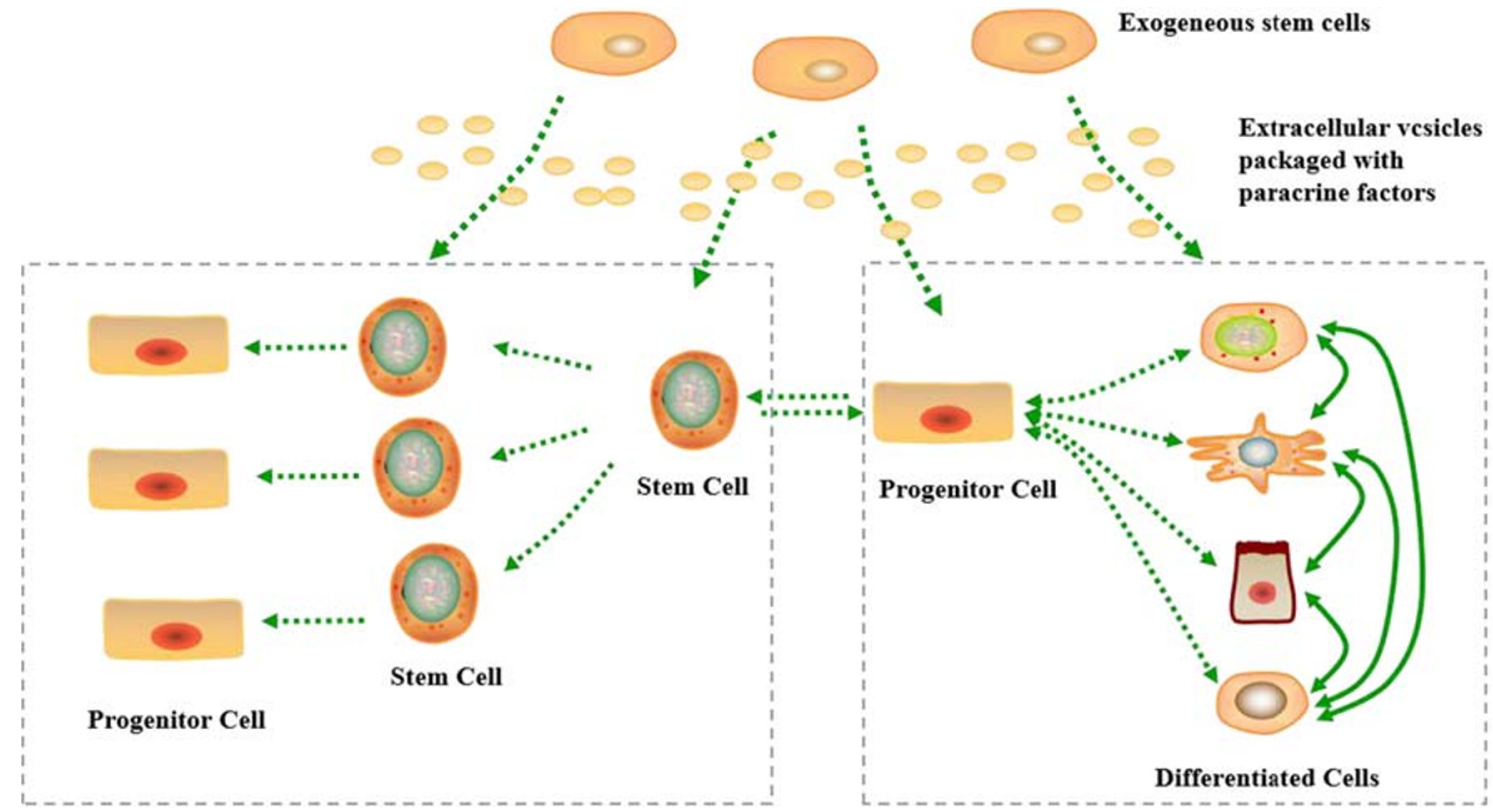

Plasticity of stem cells

Plasticity of differentiated cells

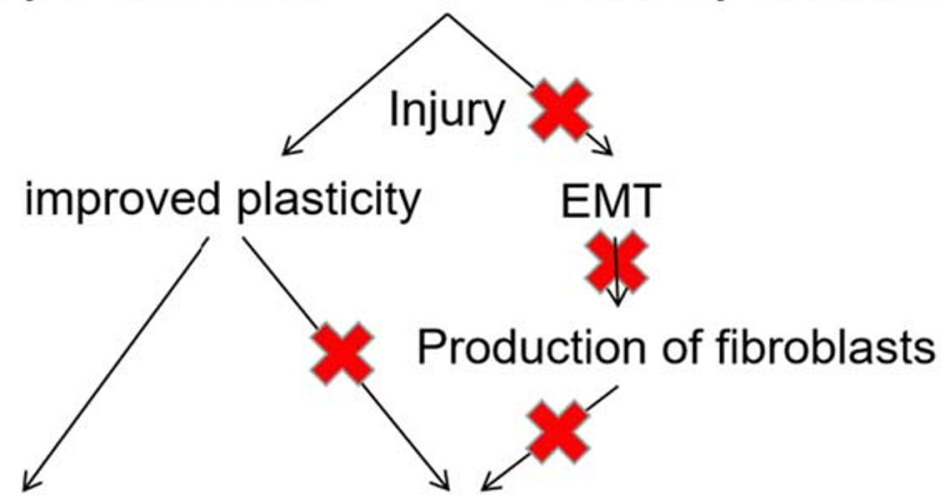

Regeneration

Fibrosis

Fig. 7 Hypothesized repair mechanism by stem cell therapy

subpopulations of endometrial cells. If the plasticity of endometrial cells could be proved to be insufficient compared to other rapidly regenerating tissues (e.g., liver, skin), the mechanism of IUA pathogenesis in cell level could be revealed.

\section{Material and Methods}

We conducted literature review in January 2020 by searching articles at PubMed on prevention and treatment, pathogenesis,
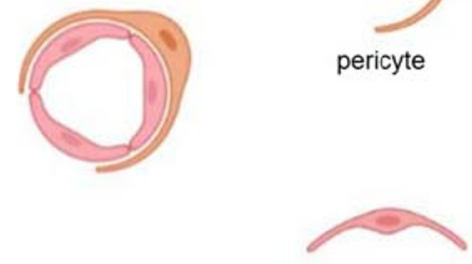

endothelial cell
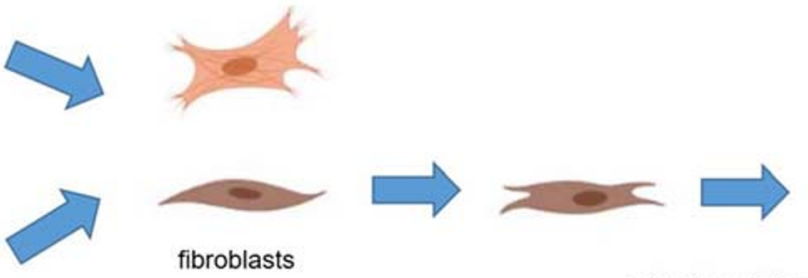

activation of fibroblasts

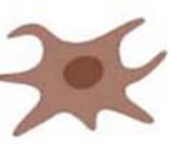


the repair of other tissues/organs, cell plasticity, and the stem cell-related therapies for intrauterine adhesion. A total of 110 articles were selected for review.

Analysis of uterine cell heterogeneity was conducted via the Human Cell Landscape (HCL) platform (http://bis.zju. edu.cn/HCL/index.html). The atlas of different types of cells in the uterus was based on the t-SNE method.

We reviewed the studies on IUA pathogenesis and selected genes that are considered to be related to IUA pathogenesis in at least two studies, or only in one study in which both the results of IUA patients and IUA animal model show that the genes related to IUA pathogenesis. These genes are combined to form a "gene combination related to IUA pathogenesis." Based on the uterine single-cell sequencing data, the expression profiles of these genes in each cell type were obtained.

Uterine single-cell sequencing of Chinese population data were retrieved from GEO database (GEO accession number GSE134355). The table listing the barcode sequence and corresponding cell type was obtained from https://figshare.com/ articles/HCL_DGE_Data/7235471. Interaction between different cell types was done at https://www.cellphonedb. org/explore-sc-rna-seq.

Author Contributions RKL - project development, manuscript writing/ editing; Yixin L-manuscript writing/editing, data analysis, and visualization; Yanhui L—project management

Data Availability The data sets used and analyzed during the current study are stated in the section of "Material and Methods" as shown above.

\section{Compliance with Ethical Standards}

Conflict of Interest All authors declare that they have no conflict of interest.

Ethics Approval This article does not contain any studies with human participants or animals performed by any of the authors.

Informed Consent This article does not contain any studies with human participants performed by any of the authors.

Open Access This article is licensed under a Creative Commons Attribution 4.0 International License, which permits use, sharing, adaptation, distribution and reproduction in any medium or format, as long as you give appropriate credit to the original author(s) and the source, provide a link to the Creative Commons licence, and indicate if changes were made. The images or other third party material in this article are included in the article's Creative Commons licence, unless indicated otherwise in a credit line to the material. If material is not included in the article's Creative Commons licence and your intended use is not permitted by statutory regulation or exceeds the permitted use, you will need to obtain permission directly from the copyright holder. To view a copy of this licence, visit http://creativecommons.org/licenses/by/4.0/.

\section{References}

1. Dreisler E, Kjer JJ. Asherman's syndrome: current perspectives on diagnosis and management. Int J Women's Health. 2019;11:1918. https://doi.org/10.2147/IJWH.S165474.

2. Schenker JG, Margalioth EJ. Intrauterine adhesions: an updated appraisal. Fertil Steril. 1982;37:593-610.

3. Taskin O, Sadik S, Onoglu A, Gokdeniz R, Erturan E, Burak F, et al. Role of endometrial suppression on the frequency of intrauterine adhesions after resectoscopic surgery. J Am Assoc Gynecol Laparosc. 2000;7:351-4. https://doi.org/10.1016/s10743804(05)60478-1.

4. Leung PL, Tam WH, Yuen PM. Hysteroscopic appearance of the endometrial cavity following thermal balloon endometrial ablation. Fertil Steril. 2003;79:1226-8. https://doi.org/10.1016/ s0015-0282(02)04956-7.

5. Asherman J. Amenorrhoea traumatica (atretica). J Obs Gynaecol Br Emp. 1948;55:23-30. https://doi.org/10.1007/s43032-02000343-y.

6. Chen Y, Liu L, Luo Y, et al. Effects of aspirin and intrauterine balloon on endometrial repair and reproductive prognosis in patients with severe intrauterine adhesion: A prospective cohort study. Biomed Res Int. 2017;2017:8526104.

7. Klemmt PA, Starzinski-Powitz A. Molecular and cellular pathogenesis of endometriosis. Curr Women s Heal Rev. 2017;13:1-11. https://doi.org/10.2174/1573404813666170306163448.

8. Brännström M, Johannesson L, Bokström H, Kvarnström N, Mölne J, Dahm-Kähler P, et al. Livebirth after uterus transplantation. Lancet. 2015;385:607-16. https://doi.org/10.1016/S01406736(14)61728-1.

9. Ejzenberg D, Andraus W, Baratelli Carelli Mendes LR, et al. Livebirth after uterus transplantation from a deceased donor in a recipient with uterine infertility. Lancet (London, England). 2019;392:2697-704. https://doi.org/10.1016/S0140-6736(18) 31766-5.

10. Brännström M, Dahm-Kähler P, Kvarnström N, Akouri R, Rova $\mathrm{K}$, Olausson $\mathrm{M}$, et al. Livebirth after robotic-assisted live donor uterus transplantation. Acta Obstet Gynecol Scand. 2020;99: 1222-9. https://doi.org/10.1111/aogs.13853.

11. Hellström M, Moreno-Moya JM, Bandstein S, et al. Bioengineered uterine tissue supports pregnancy in a rat model. Fertil Steril. 2016;106:487-496.e1. https://doi.org/10.1016/j. fertnstert.2016.03.048.

12. Körbel C, Menger MD, Laschke MW. Size and spatial orientation of uterine tissue transplants on the peritoneum crucially determine the growth and cyst formation of endometriosis-like lesions in mice. Hum Reprod. 2010;25:2551-8. https://doi.org/10.1093/ humrep/deq201.

13. Bosteels J, Weyers S, Mol BWJ, D'Hooghe T. Anti-adhesion barrier gels following operative hysteroscopy for treating female infertility: a systematic review and meta-analysis. Gynecol Surg. 2014;11:113-27. https://doi.org/10.1007/s10397-014-0832-x.

14. Healy MW, Schexnayder B, Connell MT, et al. Intrauterine adhesion prevention after hysteroscopy: a systematic review and metaanalysis. Am J Obstet Gynecol. 2016;215:267-275.e7. https://doi. org/10.1016/j.ajog.2016.05.001.

15. Johary J, Xue M, Zhu X, Xu D, Velu PP. Efficacy of estrogen therapy in patients with intrauterine adhesions: systematic review. J Minim Invasive Gynecol. 2014;21:44-54. https://doi.org/10. 1016/j.jmig.2013.07.018.

16. Salma U, Xue M, Md Sayed AS, Xu D. Efficacy of intrauterine device in the treatment of intrauterine adhesions. Biomed Res Int. 2014;2014:589296-15. https://doi.org/10.1155/2014/589296. 
17. Khan Z, Goldberg JM. Hysteroscopic management of Asherman's syndrome. J Minim Invasive Gynecol. 2018;25:218-28. https:// doi.org/10.1016/j.jmig.2017.09.020.

18. Kou L, Jiang X, Xiao S, Zhao YZ, Yao Q, Chen R. Therapeutic options and drug delivery strategies for the prevention of intrauterine adhesions. J Control Release. 2019;318:25-37. https://doi.org/ 10.1016/j.jconrel.2019.12.007.

19. Ozumba B, Ezegwui H. Intrauterine adhesions in an African population. Int J Gynaecol Obstet. 2002;77:37-8. https://doi.org/10. 1016/s0020-7292(01)00500-8.

20. Knopman J, Copperman AB. Value of 3D ultrasound in the management of suspected Asherman's syndrome. J Reprod Med. 2007;52:1016-22.

21. Malhotra N, Bahadur A, Kalaivani M, Mittal S. Changes in endometrial receptivity in women with Asherman's syndrome undergoing hysteroscopic adhesiolysis. Arch Gynecol Obstet. 2012;286:525-30. https://doi.org/10.1007/s00404-012-2336-0.

22. Coccia ME, Becattini C, Bracco GL, Pampaloni F, Bargelli G, Scarselli G. Pressure lavage under ultrasound guidance: a new approach for outpatient treatment of intrauterine adhesions. Fertil Steril. 2001;75:601-6. https://doi.org/10.1016/s0015-0282(00) 01770-2.

23. Roge P, D'Ercole C, Cravello L, et al. Hysteroscopic management of uterine synechiae: a series of 102 observations. Eur J Obstet Gynecol Reprod Biol. 1996;65:189-93. https://doi.org/10.1016/ 0301-2115(95)02342-9.

24. Chen X, Sun J, Li X, et al. Antifibrotic effects of decellularized and lyophilized human amniotic membrane transplant on the formation of intrauterine adhesion. Exp Clin Transplant. 2019;17: 236-42. https://doi.org/10.6002/ect.2017.0284.

25. Ning J, Zhang H, Yang H. MicroRNA-326 inhibits endometrial fibrosis by regulating TGF- $\beta 1 / \mathrm{Smad} 3$ pathway in intrauterine adhesions. Mol Med Rep. 2018;18:2286-92. https://doi.org/10. 3892/mmr.2018.9187.

26. Zhou Q, Wu X, Hu J, Yuan R. Abnormal expression of fibrosis markers, estrogen receptor $\alpha$ and stromal derived factor-1/chemokine (C-X-Cmotif) receptor-4 axis in intrauterine adhesions. Int $\mathrm{J}$ Mol Med. 2018;42:81-90.

27. Xue X, Chen Q, Zhao G, Zhao JY, Duan Z, Zheng PS. The overexpression of TGF- $\beta$ and $C \mathrm{CN} 2$ in intrauterine adhesions involves the NF-KB signaling pathway. PLoS One. 2015;10: e0146159.

28. Hu J, Zeng B, Jiang X, Hu L, Meng Y, Zhu Y, et al. The expression of marker for endometrial stem cell and fibrosis was increased in intrauterine adhesious. Int J Clin Exp Pathol. 2015;8:1525-34.

29. Guo L, Chen L-M, Chen F, Jiang NH, Sui L. Smad signaling coincides with epithelial-mesenchymal transition in a rat model of intrauterine adhesion. Am J Transl Res. 2019;11:4726-37.

30. Chen J, Yi X, Gu P, Gao S. The role of KDR in intrauterine adhesions may involve the TGF- $\beta 1 /$ Smads signaling pathway. Brazilian J Med Biol Res. 2019;52:e8324.

31. Salma U, Xue M, Sheikh A, et al. Role of transforming growth factor- $\beta 1$ and smads signaling pathway in intrauterine adhesion. Mediat Inflamm. 2016;2016:1-13.

32. Longo DL, Rockey DC, Bell PD, Hill JA. Fibrosis - a common pathway to organ injury and failure. N Engl J Med. 372:1138-49.

33. Wang X, Ma N, Sun Q, et al. Elevated NF- $k B$ signaling in Asherman syndrome patients and animal models. Oncotarget. 2017;8(9):15399-406.

34. Xiao L, Song Y, Huang W, et al Expression of SOX2, NANOG and OCT4 in a mouse model of lipopolysaccharide-induced acute uterine injury and intrauterine adhesions. Reprod Biol Endocrinol $15: 14$

35. Li J, Du S, Sheng X, et al. MicroRNA-29b inhibits endometrial fibrosis by regulating the Sp1-TGF- $\beta 1 /$ Smad-CTGF axis in a rat model. Reprod Sci. 2016;23:386-94.
36. Liu X, Duan H, Zhang H-H, Gan L, Xu Q. Integrated data set of microRNAs and mRNAs involved in severe intrauterine adhesion. Reprod Sci. 2016;23:1340-7.

37. Xu Q, Duan H, Gan L, et al. MicroRNA-1291 promotes endometrial fibrosis by regulating the ArhGAP29-RhoA/ROCK1 signaling pathway in a murine model. Mol Med Rep. 2017;16(4):450110.

38. Li J, Cen B, Chen S, He Y. MicroRNA-29b inhibits TGF- $\beta 1$ induced fibrosis via regulation of the TGF- $\beta 1 / \mathrm{Smad}$ pathway in primary human endometrial stromal cells. Mol Med Rep. 2016;13: 4229-37.

39. Zhu H-Y, Ge T-X, Pan Y-B, Zhang S-Y. Advanced role of Hippo signaling in endometrial fibrosis: implications for intrauterine adhesion. Chin Med J. 2017;130:2732-7. https://doi.org/10.4103/ 0366-6999.218013.

40. Strakova Z, Kruss S, Morris K, Reed J. Members of the Hippo pathway are regulated in the uterus during the menstrual cycle. Biol Reprod. 2010;83:363.

41. Strakova Z, Reed J, Ihnatovych I. Human transcriptional coactivator with PDZ-binding motif (TAZ) is downregulated during decidualization. Biol Reprod. 2010;82:1112-8.

42. Jorgenson AJ, Choi KM, Sicard D, Smith KMJ, Hiemer SE, Varelas X, et al. TAZ activation drives fibroblast spheroid growth, expression of profibrotic paracrine signals, and context-dependent ECM gene expression. Am J Physiol Cell Physiol. 2017;312: C277-85. https://doi.org/10.1152/ajpcell.00205.2016.

43. Wang Q, Xu Z, An Q, et al. TAZ promotes epithelial to mesenchymal transition via the upregulation of connective tissue growth factor expression in neuroblastoma cells. Mol Med Rep. 2015;11: 982-8. https://doi.org/10.3892/mmr.2014.2818.

44. Liu F, Lagares D, Choi KM, Stopfer L, Marinković A, Vrbanac V, et al. Mechanosignaling through YAP and TAZ drives fibroblast activation and fibrosis. Am J Physiol Lung Cell Mol Physiol. 2015;308:L344-57. https://doi.org/10.1152/ajplung.00300.2014.

45. Miranda MZ, Bialik JF, Speight P, Dan Q, Yeung T, Szászi K, et al. TGF- $\beta 1$ regulates the expression and transcriptional activity of TAZ protein via a Smad3-independent, myocardin-related transcription factor-mediated mechanism. J Biol Chem. 2017;292: 14902-20. https://doi.org/10.1074/jbc.M117.780502.

46. Ayyaz A, Attisano L, Wrana JL. Recent advances in understanding contextual TGF $\beta$ signaling. F1000Research. 2017;6:749. https://doi.org/10.12688/f1000research.11295.1.

47. Piersma B, Bank RA, Boersema M. Signaling in fibrosis: TGF- $\beta$, WNT, and YAP/TAZ converge. Front Med. 2015;2:59. https:// doi.org/10.3389/fmed.2015.00059.

48. Narimatsu M, Samavarchi-Tehrani P, Varelas X, Wrana JL. Distinct polarity cues direct Taz/Yap and TGF $\beta$ receptor localization to differentially control TGF $\beta$-induced Smad signaling. Dev Cell. 2015;32:652-6. https://doi.org/10.1016/j.devcel.2015. 02.019.

49. Papalexi E, Satija R. Single-cell RNA sequencing to explore immune cell heterogeneity. Nat Rev Immunol. 2018;18:35-45. https://doi.org/10.1038/nri.2017.76.

50. Tellez-Gabriel M, Ory B, Lamoureux F, Heymann MF, Heymann D. Tumour heterogeneity: the key advantages of single-cell analysis. Int J Mol Sci. 2016;17:2142. https://doi.org/10.3390/ ijms 17122142 .

51. Amos MR, Healey GD, Goldstone RJ, Mahan SM, Düvel A, Schuberth HJ, et al. Differential endometrial cell sensitivity to a cholesterol-dependent cytolysin links Trueperella pyogenes to uterine disease in cattle. Biol Reprod. 2014;90:54. https://doi. org/10.1095/biolreprod.113.115972.

52. Grant KS, Wira CR. Effect of mouse uterine stromal cells on epithelial cell transepithelial resistance (TER) and TNF $\alpha$ and TGF $\beta$ release in culture1. Biol Reprod. 2003;69:1091-8. https:// doi.org/10.1095/biolreprod.103.015495. 
53. Grant-Tschudy KS, Wira CR. Effect of oestradiol on mouse uterine epithelial cell tumour necrosis factor-alpha release is mediated through uterine stromal cells. Immunology. 2005;115:99-107. https://doi.org/10.1111/j.1365-2567.2005.02134.x.

54. Han X, Zhou Z, Fei L, Sun H, Wang R, Chen Y, et al. Construction of a human cell landscape at single-cell level. Nature. 2020;581:303-9. https://doi.org/10.1038/s41586-0202157-4.

55. Abad M, Hashimoto H, Zhou H, Morales MG, Chen B, BasselDuby R, et al. Notch inhibition enhances cardiac reprogramming by increasing MEF2C transcriptional activity. Stem cell reports. 2017;8:548-60. https://doi.org/10.1016/j.stemcr.2017.01.025.

56. Yang J, van Oosten AL, Theunissen TW, Guo G, Silva JCR, Smith A. Stat3 activation is limiting for reprogramming to ground state pluripotency. Cell Stem Cell. 2010;7:319-28. https://doi.org/ 10.1016/j.stem.2010.06.022

57. Efe JA, Hilcove S, Kim J, Zhou H, Ouyang K, Wang G, et al. Conversion of mouse fibroblasts into cardiomyocytes using a direct reprogramming strategy. Nat Cell Biol. 2011;13:215-22. https://doi.org/10.1038/ncb2164.

58. Ichida JK, Blanchard J, Lam K, Son EY, Chung JE, Egli D, et al. A small-molecule inhibitor of tgf-Beta signaling replaces sox 2 in reprogramming by inducing nanog. Cell Stem Cell. 2009;5:491503. https://doi.org/10.1016/j.stem.2009.09.012.

59. Naito AT, Shiojima I, Akazawa H, Hidaka K, Morisaki T, Kikuchi A, et al. Developmental stage-specific biphasic roles of Wnt/betacatenin signaling in cardiomyogenesis and hematopoiesis. Proc Natl Acad Sci U S A. 2006;103:19812-7. https://doi.org/10. 1073/pnas.0605768103.

60. Vieira JM, Riley PR. Chemical genetics and its potential in cardiac stem cell therapy. Br J Pharmacol. 2013;169:318-27. https://doi. $\operatorname{org} / 10.1111 / \mathrm{j} .1476-5381.2012 .01928 . x$.

61. Yang L, Soonpaa MH, Adler ED, Roepke TK, Kattman SJ, Kennedy M, et al. Human cardiovascular progenitor cells develop from a KDR+ embryonic-stem-cell-derived population. Nature. 2008;453:524-8. https://doi.org/10.1038/nature06894.

62. Kattman SJ, Witty AD, Gagliardi M, Dubois NC, Niapour M, Hotta A, et al. Stage-specific optimization of activin/nodal and BMP signaling promotes cardiac differentiation of mouse and human pluripotent stem cell lines. Cell Stem Cell. 2011;8:22840. https://doi.org/10.1016/j.stem.2010.12.008.

63. Silva J, Barrandon O, Nichols J, Kawaguchi J, Theunissen TW, Smith A. Promotion of reprogramming to ground state pluripotency by signal inhibition. PLoS Biol. 2008;6:e253. https://doi.org/10.1371/journal.pbio.0060253.

64. Li W, Zhou H, Abujarour R, Zhu S, Joo JY, Lin T, et al. Generation of human-induced pluripotent stem cells in the absence of exogenous Sox2. Stem Cells. 2009;27:2992-3000. https://doi.org/10.1002/stem.240.

65. Fu Y, Huang C, Xu X, Gu H, Ye Y, Jiang C, et al. Direct reprogramming of mouse fibroblasts into cardiomyocytes with chemical cocktails. Cell Res. 2015;25:1013-24. https://doi.org/ 10.1038/cr.2015.99.

66. Ladewig J, Mertens J, Kesavan J, Doerr J, Poppe D, Glaue F, et al. Small molecules enable highly efficient neuronal conversion of human fibroblasts. Nat Methods. 2012;9:575-8. https://doi.org/ 10.1038/nmeth.1972.

67. Shi Y, Do JT, Desponts C, et al. A combined chemical and genetic approach for the generation of induced pluripotent stem cells. Cell Stem Cell. 2008;2:525-8. https://doi.org/10.1016/j.stem.2008.05. 011.

68. Zhao Y, Londono P, Cao Y, Sharpe EJ, Proenza C, O'Rourke R, et al. High-efficiency reprogramming of fibroblasts into cardiomyocytes requires suppression of pro-fibrotic signalling. Nat Commun. 2015;6:8243. https://doi.org/10.1038/ ncomms 9243 .
69. Lai P-L, Lin H, Chen S-F, Yang SC, Hung KH, Chang CF, et al. Efficient generation of chemically induced mesenchymal stem cells from human dermal fibroblasts. Sci Rep. 2017;7:44534. https://doi.org/10.1038/srep44534.

70. Wang S, Xia P, Ye B, Huang G, Liu J, Fan Z. Transient activation of autophagy via Sox2-mediated suppression of mTOR is an important early step in reprogramming to pluripotency. Cell Stem Cell. 2013;13:617-25. https://doi.org/10.1016/j.stem.2013.10. 005.

71. Wells JM, Watt FM. Diverse mechanisms for endogenous regeneration and repair in mammalian organs. Nature. 2018;557:322-8.

72. Mastrogiannaki M, Lichtenberger BM, Reimer A, Collins CA, Driskell RR, Watt FM. $\beta$-Catenin stabilization in skin fibroblasts causes fibrotic lesions by preventing adipocyte differentiation of the reticular dermis. J Invest Dermatol. 2016;136:1130-42. https://doi.org/10.1016/j.jid.2016.01.036.

73. Stanger BZ. Cellular homeostasis and repair in the mammalian liver. Annu Rev Physiol. 2015;77:179-200. https://doi.org/10. 1146/annurev-physiol-021113-170255.

74. Plikus MV, Guerrero-Juarez CF, Ito M, Li YR, Dedhia PH, Zheng $\mathrm{Y}$, et al. Regeneration of fat cells from myofibroblasts during wound healing. Science. 2017;355:748-52. https://doi.org/10. 1126/science.aai8792.

75. Mills JC, Sansom OJ. Reserve stem cells: differentiated cells reprogram to fuel repair, metaplasia, and neoplasia in the adult gastrointestinal tract. Sci Signal. 2015;8:re8. https://doi.org/10.1126/ scisignal.aaa 7540 .

76. Yan KS, Gevaert O, Zheng GXY, et al. Intestinal enteroendocrine lineage cells possess homeostatic and injury-inducible stem cell activity. Cell Stem Cell. 2017;21:78-90.e6. https://doi.org/10. 1016/j.stem.2017.06.014.

77. Raven A, Lu W-Y, Man TY, Ferreira-Gonzalez S, O'Duibhir E, Dwyer BJ, et al. Cholangiocytes act as facultative liver stem cells during impaired hepatocyte regeneration. Nature. 2017;547:350 4. https://doi.org/10.1038/nature23015.

78. Stange DE, Koo B-K, Huch M, Sibbel G, Basak O, Lyubimova A, et al. Differentiated Troy+ chief cells act as reserve stem cells to generate all lineages of the stomach epithelium. Cell. 2013;155: 357-68. https://doi.org/10.1016/j.cell.2013.09.008.

79. Lu W-Y, Bird TG, Boulter L, Tsuchiya A, Cole AM, Hay T, et al. Hepatic progenitor cells of biliary origin with liver repopulation capacity. Nat Cell Biol. 2015;17:971-83. https://doi.org/10.1038/ ncb3203.

80. Leushacke M, Tan SH, Wong A, Swathi Y, Hajamohideen A, Tan LT, et al. Lgr5-expressing chief cells drive epithelial regeneration and cancer in the oxyntic stomach. Nat Cell Biol. 2017;19:774 86. https://doi.org/10.1038/ncb3541.

81. Nicolosi PA, Tombetti E, Giovenzana A, Donè E, Pulcinelli E, Meneveri R, et al. Macrophages guard endothelial lineage by hindering endothelial-to-mesenchymal transition: implications for the pathogenesis of systemic sclerosis. J Immunol. 2019;203:247-58. https://doi.org/10.4049/jimmunol.1800883.

82. Wu KQ, Muratore CS, So E-Y, Sun C, Dubielecka PM, Reginato $\mathrm{AM}$, et al. M1 macrophage-induced endothelial-to-mesenchymal transition promotes infantile hemangioma regression. Am J Pathol. 2017;187:2102-11. https://doi.org/10.1016/j.ajpath.2017. 05.014 .

83. Evrard SM, Lecce L, Michelis KC, Nomura-Kitabayashi A, Pandey G, Purushothaman KR, et al. Endothelial to mesenchymal transition is common in atherosclerotic lesions and is associated with plaque instability. Nat Commun. 2016;7:11853. https://doi. org/10.1038/ncomms 11853 .

84. Zhu X, Bruno P, Yan G, et al. Stem cells and endometrial regeneration: from basic research to clinical trial. Curr Stem Cell Res Ther. 2019;14(4):293-304. 
85. Azizi R, Aghebatimaleki L, Nouri M, et al. Stem cell therapy in Asherman syndrome and thin endometrium: Stem cell- based therapy. 2018;102:333-343.

86. Liu Y, Cai J, Luo X, Haiping Wen YL (2019) Collagen scaffold with human umbilical cord mesenchymal stem cells remarkably improves intrauterine adhesions in a rat model. Gynecol Obstet Investig

87. Zhang S, Li P, Yuan Z, Tan J. Platelet-rich plasma improves therapeutic effects of menstrual blood-derived stromal cells in rat model of intrauterine adhesion. Stem Cell Res Ther. 2019;10(1): 61.

88. Spees JL, Lee RH, Gregory CA. Mechanisms of mesenchymal stem/stromal cell function. Stem Cell Res Ther. 2016;7:125. https://doi.org/10.1186/s13287-016-0363-7.

89. Alibhai FJ, Tobin SW, Yeganeh A, Weisel RD, Li RK. Emerging roles of extracellular vesicles in cardiac repair and rejuvenation. Am J Physiol Heart Circ Physiol. 2018;315:H733-44. https://doi. org/10.1152/ajpheart.00100.2018.

90. Nargesi AA, Lerman LO, Eirin A. Mesenchymal stem cell-derived extracellular vesicles for renal repair. Curr Gene Ther. 2017;17:29_ 42. https://doi.org/10.2174/1566523217666170412110724.

91. Xu J, Wang Y, Hsu C-Y, Gao Y, Meyers CA, Chang L, et al. Human perivascular stem cell-derived extracellular vesicles mediate bone repair. Elife. 2019;8:e48191. https://doi.org/10.7554/ eLife.48191.

92. Fu X, Liu G, Halim A, Ju Y, Luo Q, Song AG. Mesenchymal stem cell migration and tissue repair. Cells. 2019;8:784. https://doi.org/ $10.3390 /$ cells 8080784

93. Abumaree MH, Al Jumah MA, Kalionis B, et al. Phenotypic and functional characterization of mesenchymal stem cells from chorionic villi of human term placenta. Stem Cell Rev Reports. 2013;9:16-31.

94. Vassena R, Eguizabal C, Heindryckx B, Sermon K, Simon C, van Pelt A, et al. Stem cells in reproductive medicine: ready for the patient? Hum Reprod. 2015;30:2014-21.

95. Nesrine E, Ola M, Ebrahim EDR, et al. Human mesenchymal stem cell-derived extracellular vesicles/estrogen combined therapy safely ameliorates experimentally induced intrauterine adhesions in a female rat model. Stem Cell Res Ther. 9:175.

96. Selvasandran K, Makhoul G, Jaiswal PK, et al. A tumor necrosis factor- $\alpha$ and hypoxia-induced secretome therapy for myocardial repair. Ann Thorac Surg. 2018;105(3):715-23.

97. Yoko N, Hidefumi, et al. Enhanced wound healing by topical administration of mesenchymal stem cells transfected with stromal cellderived factor-1. Biomaterials. 2013;34(37):9393-400.

98. Yoon-Jin K, Dong, et al. Conditioned media from human umbilical cord blood-derived mesenchymal stem cells stimulate rejuvenation function in human skin. Biochem Biophys Rep. 2018;16: 96-102.

99. Hyun-Kyung K, Seul-Gi, et al. A subset of paracrine factors as efficient biomarkers for predicting vascular regenerative efficacy of mesenchymal stromal/stem cells. Stem Cells. 2019;37(1):7788.

100. Oh EJ, Lee HW, Kalimuthu S, et al. In vivo migration of mesenchymal stem cells to burn injury sites and their therapeutic effects in a living mouse model. J Control Release. 2018;279:79-88.

101. Yoo SW, Chang D-Y, Lee H-S, et al. Immune following suppression mesenchymal stem cell transplantation in the ischemic brain is mediated by TGF- $\beta$. Neurobiol Dis. 2013;58:249-57.

102. Fang S, Xu C, Zhang Y, Xue C, Yang C, Bi H, et al. Umbilical cord-derived mesenchymal stem cell-derived exosomal
microRNAs suppress myofibroblast differentiation by inhibiting the transforming growth factor- $\beta / \mathrm{SMAD} 2$ pathway during wound healing. Stem Cells Transl Med. 2016;5:1425-39. https://doi.org/ 10.5966/sctm.2015-0367.

103. Hu L, Wang J, Zhou X, Xiong Z, Zhao J, Yu R, et al. Exosomes derived from human adipose mensenchymal stem cells accelerates cutaneous wound healing via optimizing the characteristics of fibroblasts. Sci Rep. 2016;6:32993. https://doi.org/10.1038/ srep32993.

104. Geiger A, Walker A, Nissen E. Human fibrocyte-derived exosomes accelerate wound healing in genetically diabetic mice. Biochem Biophys Res Commun. 2015;467:303-9. https://doi. org/10.1016/j.bbrc.2015.09.166.

105. Zhang B, Wang M, Gong A, Zhang X, Wu X, Zhu Y, et al. HucMSC-exosome mediated-Wnt4 signaling is required for cutaneous wound healing. Stem Cells. 2015;33:2158-68. https://doi. org/10.1002/stem. 1771 .

106. Zhao B, Zhang Y, Han S, Zhang W, Zhou Q, Guan H, et al. Exosomes derived from human amniotic epithelial cells accelerate wound healing and inhibit scar formation. J Mol Histol. 2017;48: 121-32. https://doi.org/10.1007/s10735-017-9711-x.

107. Zhang J, Guan J, Niu X, Hu G, Guo S, Li Q, et al. Exosomes released from human induced pluripotent stem cells-derived MSCs facilitate cutaneous wound healing by promoting collagen synthesis and angiogenesis. J Transl Med. 2015;13:49. https://doi. org/10.1186/s12967-015-0417-0.

108. Chen L, Tredget EE, Wu PYG, Wu Y. Paracrine factors of mesenchymal stem cells recruit macrophages and endothelial lineage cells and enhance wound healing. PLoS One. 2008;3:-e1886. https://doi.org/10.1371/journal.pone.0001886.

109. Velnar T, Bailey T, Smrkolj V. The wound healing process: an overview of the cellular and molecular mechanisms. J Int Med Res. 2009;37:1528-42. https://doi.org/10.1177/147323000903700531.

110. Mosser DM, Edwards JP. Exploring the full spectrum of macrophage activation. Nat Rev Immunol. 2008;8:958-69. https://doi. org/10.1038/nri2448.

111. Sano S, Itami S, Takeda K, Tarutani M, Yamaguchi Y, Miura H, et al. Keratinocyte-specific ablation of Stat3 exhibits impaired skin remodeling, but does not affect skin morphogenesis. EMBO J. 1999;18:4657-68. https://doi.org/10.1093/emboj/18.17.4657.

112. Chen L, Guo S, Ranzer MJ, DiPietro LA. Toll-like receptor 4 has an essential role in early skin wound healing. J Invest Dermatol. 2013;133:258-67. https://doi.org/10.1038/jid.2012.267.

113. Zhang B, Wu X, Zhang X, Sun Y, Yan Y, Shi H, et al. Human umbilical cord mesenchymal stem cell exosomes enhance angiogenesis through the Wnt $4 / \beta$-catenin pathway. Stem Cells Transl Med. 2015;4:513-22. https://doi.org/10.5966/sctm.2014-0267.

114. Tao S-C, Guo S-C, Li M, Ke QF, Guo YP, Zhang CQ. Chitosan wound dressings incorporating exosomes derived from microRNA-126-overexpressing synovium mesenchymal stem cells provide sustained release of exosomes and heal fullthickness skin defects in a diabetic rat model. Stem Cells Transl Med. 2017;6:736-47. https://doi.org/10.5966/sctm.2016-0275.

115. Kano A, Wolfgang MJ, Gao Q, Jacoby J, Chai GX, Hansen W, et al. Endothelial cells require STAT3 for protection against endotoxin-induced inflammation. J Exp Med. 2003;198:151725. https://doi.org/10.1084/jem.20030077.

Publisher's Note Springer Nature remains neutral with regard to jurisdictional claims in published maps and institutional affiliations. 